\title{
A Second Look: Stakeholders' Perceptions of Some Issues in Design-Bid-Build Procurement Practice in Nigeria
}

\author{
Martin Oloruntobi Dada \\ Department of Building, University of Lagos \\ Akoka, Yaba, Lagos, Nigeria \\ E-mail: mdada@unilag.edu.ng
}

Received: November 8, 2011

Accepted: December 12, 2011 Published: January 1, 2012

doi:10.5539/jsd.v5n1p55

URL: http://dx.doi.org/10.5539/jsd.v5n1p55

\begin{abstract}
The construction product is an outcome of many procurement possibilities, among which the most dominant has been the design-bid-build (otherwise called the traditional) method. The procurement method's real or perceived drawbacks have warranted or even been rationalized for the emergence of alternative methods. Yet there is a continued use of the method in both private and public sector projects in Nigeria. This study thus sought to investigate stakeholders' perception on the use of the traditional method. 241 questionnaires were administered purposively on construction industry client, consulting and contracting organizations. 100 were received and analyzed through the use of descriptive and inferential statistical tools. Respondents were requested to express their agreement or otherwise with twenty issues raised from literature and practice on the traditional project procurement. The aggregated rankings for the stakeholder organizations show that 'where sought at all, inputs of contractors are at best advisory' ranked first among issues being assessed on traditional project procurement practice. 'Relationships among participants breed mistrust' ranked least among the twenty issues. The results of the analysis further indicate that there are no significant differences between the three stakeholder groups on some selected issues in traditional project procurement practice and documentation. It is recommended that the homogeneity of perceptions about the traditional method can be a springboard and form a baseline for further intervention efforts at improving construction project procurement in Nigeria.
\end{abstract}

Keywords: Design-bid-build, Procurement, Stakeholders, Nigeria

\section{Introduction}

The state of the construction industry of a nation can signal the direction of development in a nation. This is because the industry is responsible for the provision of infrastructure and contribution to the gross domestic product of the country (Dada \& Oladokun, 2008; Ogunlana, 2010). Physical and infrastructural development is tied to the industry. Even the shelter for the mobilization and deployment or development of intangible assets for human development is provided by the industry. The industry is responsible for the provision of shelter, buildings and other infrastructure that adds to, or supports the quality of life of the citizenry. Whichever method is used to procure projects, infrastructure development remains a sine-qua-non to national development (Dada et al., 2006). While this is so, especially in the light of the fact that the traditional method has been the oldest and most dominant in some countries (Gordon, 1994; Ling et al., 2003; Nubi, 2003) and that stakeholders in some countries are clamoring for newer methods, the reality in some countries is that the method remains the most fashionable option for project delivery in both the private and public sectors. While the construction industry has been seen as a multi-party business (Rahman \& Kuraswamy, 2002), the organization for the procurement of the construction project or product is often-times a temporary multi-organization (Newcombe et al., 1990; Murray et al., 1999). These features combine to explain the peculiar nature of the industry. Erikkson (2008) indicated that construction transactions are characterized by high complexity, customization, long duration and high uncertainty.

The traditional project procurement method has been the most dominant in the procurement of building works in many countries (Gordon, 1994; Ling et al., 2003; Nubi, 2003). Its continued use and dominance in the procurement of public and private sector works in some countries including Nigeria has been reported. Idoro, Iyagba and Odusami (2007) investigated the situation in Nigeria and concluded that the traditional method remains the most dominant and preferred or fashionable method in the letting of both public and private works. This development subsists in spite of the fact that Naoum (2003) posits in his work that the traditional project 
procurement is obsolete. This is also in spite of the fact that the traditional method has been criticized severally for what are regarded or perceived as its shortcomings. However, Erikkson (2008) had reasoned that while clients want to establish more co-operative relationships with contractors, obviously through alternative procurement methods, their choice of procurement methods is not consistent with their wish. Erikkson (2008) in his investigation thus concludes that there is a difference between desired situation and actual behavior possibly due to earlier experience. The inference from the works of Erikkson (2008) is that there is a gap between reality and actual behavior. In this regard, this study set out to investigate perceptions of three stakeholders, clients, consultants and contractors, on issues that have to do with the practice of the traditional project procurement. It is set out to investigate empirically how stakeholders perceive some issues regarding the traditional procurement method in the Nigerian construction industry. The study has the potential for contributing to the body of knowledge on traditional procurement in Nigeria and also illuminating the use of the method. The relevance of the investigation of those perceptions is that perceptions, whether right or wrong, have been argued to affect responses, decisions and market behavior and customer patronage. Perceptions may be subjective and intangible, yet they have the power to influence objective reality and the tangible (Weaver, 1981; Smith \& Nagle, 1995). The implication is that in an age of increased competitiveness, the management of perceptions of stakeholders in an endeavor can have effect on the success of the endeavor. It is thus in this context that an empirical investigation is made into assessment of issues on traditional project procurement. Furthermore, the client, consultants and contractors form a tripod of those who often take and/or implement procurement decisions on the construction project. Investigating their views and perceptions is a possible step for understanding procurement decisions in the environment of the research. An audit of the knowledge base and perceptions becomes relevant. It is presumed that this knowledge base could form an informed baseline for further researches and intervention efforts in procurement in Nigeria in general and the traditional method in the same clime in particular.

\section{Foundations of Design-Bid-Build Procurement}

Procurement is the organizational design that determines the line of relationships and communication between and among project participants among which are clients, contractors and consultants. The contractual arrangement and organizational deployment of participants for the realization of the building project matters. The design-bid-build (otherwise called the traditional) method retains the name traditional as in Rowlinson (1999) because it is an offshoot of the differentiation between designers and contractors. In this method the owner or client contacts an architect or an engineer, as the case may be, who appoints other consultants to design, and then construction is awarded to a contractor. A primary feature of this method is that design is separated from construction. Furthermore there is a serial, sequential approach to the design and construction. The concept of traditional procurement method imposes a contractual and organizational separation of design from construction.

Procurement is perceived by researchers and practitioners from several worldviews. The views include: view of organization as a system (scientific management); biological organism (system approach); states of flux and transformation; a socio-technical framework (McDermott, 1999 citing Green (1994)) Furthermore among perspectives to the study of selection of procurement is the situational or contingency approach. This perspective acknowledges that no single procurement method is applicable and adaptable to all situations (Yinghui \& Eng, 1999; Rowlinson, 1999). No one method is a cure-all. A related perspective is the socio-technical perspective. The approach assumes that the selection of procurement method cannot just be based on objective data alone but on a combination of objective and subjective reality. It acknowledges the interaction between objective and subjective reality-the human aspect. The subjective reality though intangible can have tangible and far-reaching influence on procurement selection. As human beings are not mechanistic, they play a part in the procurement process and thus influence procurement decisions.

Some works exist on procurement in Nigeria. While some have compared some procurement paths, others dwell on procurement selection and performance. Ogunsanmi, Iyagba and Omirin (2001) investigated the factors contributing to the performance of procurement path between the traditional method and the labor only method. Ojo (2009) investigated the performance of procurement types in Nigeria using the concept of performance indices. He acknowledged that the traditional procurement method is the most commonly used in the country, a position also supported by Babatunde, Opawole and Ujaddugbe (2010). Ojo (2009) further investigated a variant of the traditional method (lump sum contract method), management contracting method, design and build, build-own-operate-transfer. None of these or other works have brought together a combination of the twenty issues used in this research to ascertain stakeholder perceptions regarding traditional project procurement in general and in Nigeria in particular. Herein is found the potential contribution of this research work and the gap 
it intends to fill.

\section{Perceptions}

The subject of perception in literature often refers to the way an object or issue or personality appears in the eyes of the beholder. Perception is the way man gives interpretations to sensory stimuli. The perception of an object depends on the object, the beholder and the environment (Hodgets, 1984; Wilson \& Hanna, 1990; Robbins, 1998). Some factors often combine to determine how an issue or object is perceived and those factors include the experience of the beholder, the expectation of the beholder, and the environment or context of the situation, and the object itself. As a consequence, no two perceptions can be same. Perceptions can be subjective and individualistic impressions formed over time; yet man's decisions and reactions on issues is a function of perception. Some authors have opined or hinted that perceptions influence decision making (Prapatpaow \& Ogunlana, 2002; Weaver, 1981). This view is further reinforced by the proposition of Smith and Nagle (1995) who argued that, in marketing, buyers frequently form frames of reference when making buying decisions and these frames in turn influence how they respond to price and product information. Smith and Nagle (1995) locate this behavior in the prospect theory, which integrates the psychology of decision evaluations with the economic theory of the consumer. The theory argues that gains and losses are valued differently.

In essence, decisions, responses and actions are sometimes influenced by perceptions, which though may be subjective; nonetheless determine actions, reactions and interrelationships among individuals and organizations. This view seems to be corroborated by Kulatunga, Amaratunga, Haigh and Rameezdeen (2006) who referred to the three component model that attitude includes feeling, thought and behavior. This implies that attitudes and reactions are affected by factors that include perception. The real world is a world affected by man's perceptionsa mixture of objective "reality" and subjective interpretations of that reality. The construction industry with her processes and practices is part of the real world or society that includes both her internal and external stakeholders. How the stakeholders perceive the industry in terms of structure, organization and other issues thus has the potential of affecting patronage or the ownership of those processes. Construction project procurement covers the processes and organizational arrangement of bringing into being a building project. Among the procurement options is the traditional procurement method which though has been acknowledged as the historically most dominant method, yet it has been a subject of intense criticisms and debate regarding its drawbacks and by implication its continued usefulness. This study is underscored by the fact that despite the general criticisms in literature, the traditional method retains her dominance in the letting of both public and private sector projects in Nigeria (Idoro et al., 2007; Ojo, 2009). The study thus seeks to investigate perceptions held in the environment of the research regarding the traditional procurement processes and practice. Do some criticisms subsist? The study has the potential of turning out to be the image audit of the traditional project procurement by contracting, consulting, and client organizations. As the stakeholder organizations are individual and distinct commercial entities with enlightened objectives and self interest, the study further seeks to investigate if there are significant differences in the perceptions across the stakeholder organizations.

It is the duty or rather in the interest of any organization to create a good public image of herself and her processes. Moore (1984) argued that this requires a determined and continuous effort in correctly communicating to the public at large and to special sections of the public the nature, purpose, objectives and achievements of the organization. Decision and responses and activities have been influenced by perceptions which though may be argued to be subjective, nonetheless sway the hearts of people in their actions and reactions in individual and organizational relationships.

The perceptions held by stakeholders can thus be a useful guide for understanding or strengthening procurement performance and provide baseline information for any desired improvement, policy formulation and intervention efforts in the industry. Herein lays the relevance of this work: to provide informed opinions held by stakeholders regarding the traditional project procurement.

\section{Research Methods}

A review of relevant literature was done to distil issues that might warrant testing statistically in the research environment. The study involved the administration of questionnaires to construction industry organizations. The opinion survey questionnaires were administered on client, consulting and contracting organizations which were drawn from both the private and public sectors in Nigeria. Contractors were limited to building and civil engineering contractors. Consultants were professional firms who by training were involved in building project development. They included architects, civil/structural engineers, electromechanical engineers, quantity surveyors, land surveyors, estate surveyors, town planners and builders. Responses for the questionnaires were received from fifteen states of Nigeria in addition to Abuja, the Federal Capital Territory. As much as practicable 
except in only one instance, all questionnaires were administered on the respective organizations and completed by construction industry professionals in those organizations. The goal was to ensure that respondents were not novices but persons who could understand and appreciate the research and thus reduce the element of bias. The obvious deviant case was an experienced contractor who had professionals under him but decided to supply the information himself.

The first part of the questionnaire sought to know the personal variables of the respondent supplying information for the organization. The variables were: age group of respondent, profession, grade of membership in professional body, highest educational qualification, and years of experience in construction industry or service. The second subdivision addressed organizational variables: head office location, number of employees, annual turnover range for the last five years where applicable, ownership structure of organization, age of organization in practice, frequency of commissioning of construction works, construction industry professionals present within or without the organization, and what they do.

The questionnaire also asked respondents to assess their agreement or otherwise with twenty issues raised about traditional project procurement documentation and practice. The responses were inputted thus: 'strongly disagree' was assigned ' 1 ', 'disagree' was assigned'2', 'agree' was assigned ' 3 ', while 'strongly agree' was assigned '4'. The ratings or the values of 1 to 4 were deliberately assigned to exclude and to foreclose the position of neutrality and to make respondents take a position. It was reasoned that this approach would force respondents to think through more than when the 'neutral' position or option is provided. It is also reasoned that in the process categorical outcomes are possible: either a respondent agrees or disagrees on an issue will be apparent.

The method used for the sampling was the purposive and snowballing technique. Many reasons account for this development. There was no available and reliable record of construction industry contractors. Many are not registered with The Federation of the Construction Industry (FOCI); those who register are not under any legal mandate to do so; those who are not registered with them are more in number than those who are registered and can often be grouped as part of the informal industry which however contribute to a greater part of construction output (Adegbile et al., 2001).

The twenty items used in assessing perceptions about the traditional procurement method were gathered individually or severally from literature and practice. As those issues were collections of issues to be used newly in this investigation, it was judged necessary to test the items for both reliability and validity. While reliability measures the stability of an instrument, validity investigates the extent to which an instrument measures the hemisphere of a subject matter. For this research the split half reliability was computed at 5\% level of significance. The value of the parallel form reliability coefficient that also takes care of inter-item correlations, of 0.945 was obtained, which value was judged acceptable by the researcher. The content validity was done through assessment of the instrument by experts in the built environment.

\section{Analysis and Results}

Lagos State houses the head offices of the highest number of the organizations (with a frequency of 68 which translated to 68\%) for the opinion survey instrument. Enugu State houses 6 (6\%). Rivers, Abuja, Kwara follow in the trail of Enugu state housing $3(3 \%)$ respondent organizations each. For the observation that Lagos State houses the head offices of the highest number of respondents, the possible explanation is that Lagos remains the commercial nerve center of Nigeria. Lagos state used to house the capital city of the Federal Government of Nigeria until 1991 when the seat of Government was moved to Abuja. The descriptive and inferential statistical analyses are further presented.

\subsection{Descriptive Statistical Analysis}

Table 1 shows the response rate and classification of respondent organizations used in the study. 71,84 and 86 questionnaires were administered respectively on client, consulting and contractor organizations. The respective response rates for each group were $49 \%, 39 \%$ and $41 \%$. The aggregated response rate for the three groups was of $41.5 \%$ as indicated in column 4 of Table 1.

Table 2 indicates the professional affiliation of respondents. Architects constituted 10 (10\%), builders 27 (27\%), civil structural engineers 21 (21\%), quantity surveyors $15(15 \%)$, estate surveyors $12(12 \%)$. The profession of 1 respondent was not indicated. However, for building design and construction, architects, engineers, builders and quantity surveyors are core participants. Their number outweighed the other built environment profession of estate surveying. It should however be noted that the questionnaires were not administered on just any individuals based on professional affiliation but on the basis of the organization to which they belonged: client, consulting and contracting organizations. However care was taken to ensure that the questionnaires were 
completed by construction industry professionals in those organizations. It should be noted however that in Nigeria, builders are regarded by law as professionals who have got the requisite training and education in the profession of building and have been registered by the Council of Registered Builders of Nigeria (CORBON). CORBON is the professional regulatory body for the building profession in Nigeria. They are to be distinguished from contractors who are business persons. This is the contextual understanding of the term in Table 2. In this report all references to builder except the ones in quote refer to a professional person as explained here.

Table 3 shows the highest academic qualifications of respondents. Two (2\%) of individuals who stood for their respondent organizations had doctorate degrees, 21 (21\%) had masters degree while $42(42 \%)$ had the bachelors degree. $28(28 \%)$ had the higher national diploma qualification while $2(2 \%)$ had the national diploma. The insight that can be gained from the table is that each respondent had educational exposure with $98 \%$ having at least a degree or equivalent qualification. It can be argued that the strength of their understanding and responses could be better guaranteed.

Table 4 indicates the experience of the organizations' representatives in the construction industry. The table indicates that the highest number of respondents $15(42.9 \%)$ in the contractor organizations had experience of more than 15 years in the construction industry. In the client group, the same scenario holds: majority of respondents- $14(43.8 \%)$ - in the group has experience of more than 15 years. The same trend holds for the consultants' group. The aggregation indicates that $41(41 \%)$ of the respondents has more than 15 years experience in the construction industry.

Table 5 is a presentation of the mean item scores for the assessment of issues on traditional procurement by the three respondent organizations. The table also indicates the respective rankings by the respondent groups of the various issues used to assess the traditional procurement method. 'Where sought at all, inputs of contractors are at best advisory' is ranked most critical by the contractor respondent groups while the same issue is ranked second by the consultant group. The client group ranked the issue fifth. On the whole for the issue, the aggregated rank is 1 . The next issue that follows in aggregated ranking is 'individual participants are exploitative of loopholes in contract documents'. The issue that was ranked least on the basis of mean item score is 'relationships among participants breed mistrust'. It should be recalled that the ordinal measure of agreement is from 1 to 4 . While the value of 1 implies 'strongly disagree', 2 implies 'agree', 3 implies 'agree' and 4 is 'strongly agree'. The implication is that mean item scores approximating 3 or 4 suggest that for a specific issue, the mean item score is indicating or suggesting the respondents' agreement with the statement or issue. The reverse is also true. Mean item scores approximating 1 or 2 suggest that on the issue, the assessment of respondents reflects disagreement with the issue under consideration. In this context it is apparent that all respondent groups including the aggregated group express disagreement with the last six items or issues for assessment in the table. The groups as reflected in the table showing the descriptive analysis do not agree with some of the issues raised about the traditional project procurement practice and documentation. For example, none of the two groups agree with the issue that 'Relationships among participants breed mistrust'. This result is at variance with submission in literature that relationships among project participants are adversarial. Is this opinion suggesting that the traditional project procurement method is already perfected in Nigeria and as such respondents hold this opinion? Or is it that the two groups are just convenient with their past experience or tradition with the design-bid-build procurement. This issue warrants further investigation in another research.

The responses to the last four issues used for assessment indicate that each respondent group does not agree individually with those issues. The issues include: 'It does not encourage commitment to project objectives rather individual participants objectives'; 'It increases exposure of participants to litigation'; 'It does not encourage commitment of all participants to total quality right from project design'; 'Relationships among participants breed mistrust'. An exhaustive discussion of the each issue of assessment is not attempted here for space considerations, but the table has at least highlighted issues that the three project participant groups individually disagree with. The research finding has an ally in the work of Erikkson (2008) where empirical results do not match literature arguments or presentations.

\subsection{Inferential Statistical Analysis}

The next step in the research is to investigate whether there are significant differences between the stakeholder organizations on the documentation and practice of the traditional procurement method. In this regard, the following null and alternative hypotheses were set up:

Null Hypothesis $\left(\mathrm{H}_{0}\right)$ : There is no significant difference between the stakeholder organizations on the documentation and practice of the traditional procurement method.

Alternative Hypothesis $\left(\mathrm{H}_{1}\right)$ : There is no significant difference between the stakeholder organizations on the 
documentation and practice of the traditional procurement method.

To test the hypothesis that there are no significant differences in perceptions among the three groups, contractors, consultants and clients, the non-parametric Kruskal Wallis test is used. The test can be used when there is no assumption of normality; when there is no assumption of equality of means and variances. The Kruskal Wallis test can be likened to the non-parametric equivalent of the analysis of variance. Table 6 shows the results of the analysis.

The statistical level of test of significance has been set at $5 \%$. An examination of the table (Table 6) shows the p-values. All values above 0.05 indicate non-significant difference among the stakeholders with respect to the issue at stake. This implies an acceptance of the null hypothesis. P-values lower than 0.05 suggests significant differences among the stakeholders on the issue at stake and warrants a rejection of the null hypothesis. In this table all the p-values are more than 0.05. This implies that there are no significant differences among the stakeholders on all the issues used for assessment. The results of the analysis presented in Table 6 thus indicate that there are no significant differences among the stakeholders on the issues raised regarding the practice and documentation of the traditional project procurement.

There are several implications of this finding. The three stakeholder groups do not have significant differences on the issues. This tends to suggest a commonality or homogeneity of views on the procurement method. The work of Dada (2007) analyzing perceptions of stakeholders on priorities in public project implementation in Nigeria is handy. Even though the focus of that work is not on traditional procurement, the relevant aspect of the work is stakeholder perception. Dada's (2007) work suggests the importance of carrying along stakeholders in the implementation of public projects. It further reports that the failure of many public or multilateral projects has been due among others to the failure of carrying along host communities and other stakeholders in the planning for and execution of public projects. The earlier restiveness in the Niger Delta area of Nigeria which had recently abated due to the Federal Government organized amnesty program underscores the importance of carrying along host communities in project implementation. By extension of logic and drawing from the work of Dada (2007) referred to above, the stakeholders perception reported to exhibit no significant differences on issues has implications for practice among others. This is further interesting if the three organizational groups that are different commercial or legal entities could have a concurrence of views. The extended implication is that there is no perception gap. As there is no perception gap, the potential for unanimity of purpose stemming that could be leveraged on when evolving intervention efforts or policy considerations for construction procurement improvement exists. This is also reinforced by the finding that many public projects or projects fail due to failure to carry along and regard the views of critical stakeholders.

\section{Conclusions and Recommendations}

The study distilled from literature and practice some views held about or criticisms trailing the traditional procurement. Those views were subjected to empirical investigation and analysis in the Nigerian environment. In their assessment, what consultants rank first is that project participants are exploitative of loopholes in contract documents. On the other hand, what contractors rank first is that: where sought at all, inputs of contractors are at best advisory. The consultant' group assess the issue that the traditional project procurement practice encourages claim consciousness among participants. The analysis of the assessment of respondent organizations indicates that the issue that was ranked first by respondents on an aggregated level is: "where sought at all, inputs of contractors are at best advisory'. The respondent groups do not agree with the statement that 'Relationships among participants breed mistrust' and as such ranked it least among the twenty issues. Some of these findings, such as the one on relationship, are at variance with literature position thus confirming a gap between expectation and practice or reality about traditional procurement in the research environment. Furthermore, the statistical test revealed that there are no significant differences among the groups on all these issues. The practice, research or policy implication of the finding is that the homogeneity of perceptions can be a launching pad for further investigation and intervention efforts for procurement improvement in Nigeria.

\section{References}

Adams, O. A. (1992). Management training needs of Nigerian indigenous contractors and their preferred delivery systems. Unpublished $\mathrm{PhD}$ Thesis, University of London, London.

Adegbile, M. B. O., Dada, M. O., Iyagba, R. O. A. \& Nubi, T. O. (2001). Construction cycle: The Nigerian Experience. Professional Builder, July, 25 - 43.

Babatunde, S. O., Opawole, A. \& Ujaddugbe, I. C. (2010). An appraisal of project procurement methods in the Nigerian construction industry. Civil Engineering Dimension, 12 (1), 1-7. 
Bamisile, A. (2004). Building production management. Lagos: Foresight Press Ltd.

Dada M. O., Okikiolu, M. B. \& Oyediran, S. O. (2006). A survey of public-private-partnership in Nigerian project procurement, In Aouad. G., Kagioglou, M., Harris. K., deRidder, H., Vrijhoef, R. \& vanden Broek, C. (Eds., pp. 426-442). The third International Salford Centre for Research and Innovation (SCRI) Symposium. University of Salford.

Dada, M. O. \& Oladokun, G. B. (2008). Critical success factors in public-private-partnership projects in Nigeria: A perceptual Survey. In Karter, C., Ogunlana, S. O. \& Kaka, A. (Eds., pp. 1-10). Transformation through construction: Joint 2008 CIB W065/055 Symposium proceedings. Edinburgh, Herriot Watt University.

De-Valence, G. \& Houn, N. (1999). Procurement strategies. In Best, R and De- Valence, G. Building in value. Australia: Arnold and the Contributors.

Erikkson, P. E. (2008). Procurement effects on coopetition on client contractor relationships. Journal of construction Engineering and Management, 134 (2), 103-111. http://dx.doi.org/10.1061/(ASCE)0733-9364(2008)134:2(103)

Freeman-Bell, G. \& Balkwill, J. (1993). Management in Engineering: Principles and practice. Prentice Hall International UK.

Gordon, C. M. (1994). Choosing appropriate construction contracting method. Journal of Construction $\begin{array}{lllllll}\text { Engineering and } & \text { Management, } & 120 & (1), & 196 & - & 210 .\end{array}$ http://dx.doi.org/10.1061/(ASCE)0733-9364(1994)120:1(196)

Hodgetts, R. M. (1984). Modern Human Relations at Work (2nd Ed). New York: CBS College Publishing.

Idoro, G. I. (2007). A comparative evaluation of health and safety performance of indigenous and multinational construction firms in Nigeria. Construction Research Journal, 1 (1), 65-75.

Idoro, G. I., Iyagba, R. O. A. \& Odusami, K. T. (2007). Evaluation of the use of design-bid-build procurement system in the Nigerian construction industry. Construction Research Journal, 1 (1), 15-25.

Kaming, P. F., Holt, G. D., Kometa, S. T. \& Olomolaiye, P. O. (1998). Severity diagnosis of productivity problems - A reliability analysis. International Journal of Project Management, 16 (2), 107 -113. http://dx.doi.org/10.1016/S0263-7863(97)00036-7

Kinnear, P. R. \& Gray, C. D. (2000). SPSS for windows made simple: Release 10. UK: Psychology press Ltd.

Kozlowski, S. W. J. \& Ilgen, D. R. (2006). Enhancing the effectiveness of workgroup and teams. Psychological science in the public interest, 7 (30), 77-124.

Kulatunga, U., Amaratunga, D., Haigh, R. \& Rameezdeen, R. (2006). Attitudes and perceptions of construction workforce on construction waste in Sri Lanka. Management of Environmental Quality: An International Journal, 17 (1), 57 -71. http://dx.doi.org/10.1108/14777830610639440

Kumaraswamy, M. M. \& Dissanayaka, S. M. (1998). Linking procurement systems to project priorities. Building Research and Information, 26 (4), 223 - 238. http://dx.doi.org/10.1080/096132198369832

Lee-Kenley, L. (2006). Locus of control and attitudes to working in virtual teams. International Journal of Project Management, 24, 234-243. http://dx.doi.org/10.1016/j.ijproman.2006.01.003

Ling, Y. N., Ofori, G. \& Low, S. P. (2003). Evaluation and selection of consultants for design-build. Projects. Project Management Journal, 34 (1), 12 - 22.

Mills, A. \& Skitmore, M. (1999). A comparison of client and contractor attitudes to pre-qualification criteria, In Ogunlana, S. O. (Ed., pp.699-708). Profitable partnering in construction procurement. London: E \& FN Spon Limited.

Naoum, S. G. (2003). An overview of the concept of partnering. International Journal of Project Management, 21 (1), 71-76. http://dx.doi.org/10.1016/S0263-7863(01)00059-X

Nubi, T. O. (2003). Construction procurement: Need for paradigm shift. Building Quarterly, 1 (10), 17-27.

Odusami, K. T. (2001). Project team leadership and construction project performance in some selected states of Nigeria. Unpublished PhD Thesis. University Of Lagos, Lagos.

Ogunlana, S. O. (2010). Sustaining the 20:2020 vision through construction: A stakeholder participatory approach. Distinguished lecture Series of the School of Postgraduate Studies. University of Lagos, delivered on February 10, 2010. 
Ogunsanmi, O. E., Iyagba, R. O. A. \& Omirin, M. M. (2001). Modeling procurement performance in housing projects in Nigeria. The Lagos Journal of Environmental Sciences, 3 (1), 16-35.

Ojo, S. O. (2009). Benchmarking the performance of construction procurement methods against selection criteria in Nigeria. Civil Engineering Dimension, 11 (2), 106-112.

Robbins, S. P. (1998). Organisational Behaviour: Concepts, Controversies and Applications (8th Ed). New Delhi: Prentice Hall of India Private Limited.

Rowlinson, S. (1999). Selection criteria. In Rowlinson, S. \& McDermott, P. (Eds., pp. 276 - 299) Procurement systems: A guide to best practice in construction. London: E \& FN Spon Ltd.

Smith, G. E. \& Nagle, T. T. (1995). Frames of reference and buyers' perception of price and value. California Management Review, 38 (1), 98 - 116.

Weaver, R. L. (1981). Understanding interpersonal communication. US: Scott Freeman and Co.

Wilson, G. L. \& Hanna, M. S. (1990). Groups in context: Leadership and participation in small Groups. New York: McGraw Hall Publishing Company.

Table 1. Response rate and classification of respondents

\begin{tabular}{|c|c|c|c|c|}
\hline No of questionnaire & $\begin{array}{c}\text { No and \% from } \\
\text { Contractor } \\
\text { organization }\end{array}$ & $\begin{array}{c}\text { No and \% from } \\
\text { Client organisations }\end{array}$ & $\begin{array}{c}\text { No and \% from } \\
\text { consultant organizations }\end{array}$ & $\begin{array}{c}\text { Total no. and \% from } \\
\text { group }\end{array}$ \\
\hline Received & $35(41 \%)$ & $32(49 \%)$ & $33(39 \%)$ & $100(41.5)$ \\
\hline Not received & $51(59 \%)$ & $39(51 \%)$ & $51(61 \%)$ & $141(58.5)$ \\
\hline Total & $86(100 \%)$ & $71(100 \%)$ & $84(100 \%)$ & $241(100)$ \\
\hline
\end{tabular}

Table 2. Professional affiliations of respondents

\begin{tabular}{|c|c|c|c|c|c|c|c|c|}
\hline Professionals & NCTG & $\%$ CTG & NCLG & \%CLG & NCSG & $\%$ CSG & $\begin{array}{c}\text { NTOT } \\
\text { G }\end{array}$ & $\begin{array}{c}\text { \%OT } \\
\text { G }\end{array}$ \\
\hline Architect & - & - & 3 & 9.40 & 7 & 21.20 & 10 & 10 \\
\hline Builder & 12 & 34.30 & 12 & 37.5 & 3 & 9.10 & 27 & 27 \\
\hline Civil/structural engineer & 9 & 25.70 & 6 & 18.80 & 6 & 18.20 & 21 & 21 \\
\hline Mechanical engineers & 2 & 5.70 & 2 & 6.30 & 2 & 6.10 & 6 & 6 \\
\hline Estate surveyors & 2 & 5.70 & 3 & 9.40 & 7 & 21.20 & 12 & 12 \\
\hline Quantity surveyors & 5 & 14.30 & 4 & 12.5 & 6 & 18.20 & 15 & 15 \\
\hline Dual or more professions & 4 & 11.40 & 2 & 6.30 & 2 & 6.10 & 8 & 8 \\
\hline Not indicated & 1 & 2.90 & - & - & - & - & 1 & 1 \\
\hline Total & 35 & 100 & 32 & 100 & 33 & 100 & 100 & 100 \\
\hline
\end{tabular}

NTCG = number in contractor's group; $\mathrm{CTG}=$ Contractors group; $\mathrm{NCLG}=$ Number in client group; CLG $=$ client group; NCSG =Number in consultant's group; $\mathrm{CSG}=$ consultant's group; NTOTG $=$ Number in all the groups; TOTG $=$ total for all the groups

Table 3. Highest academic qualifications of respondents

\begin{tabular}{|c|c|c|c|c|c|c|c|c|}
\hline Highest qualification & NCTG & \%CTG & NCLG & \%CLG & NCSG & \%CSG & NTOTG & \%TOTG \\
\hline PhD & & & & & 2 & 6.00 & 2 & 2 \\
\hline Masters & 9 & 25.60 & 6 & 18.70 & 8 & 24.00 & 23 & 23 \\
\hline Bachelors & 14 & 40.00 & 18 & 56.30 & 11 & 33.30 & 43 & 43 \\
\hline Higher National Diploma & 8 & 22.80 & 8 & 25.00 & 12 & 36.40 & 28 & 28 \\
\hline National Diploma & 2 & 5.80 & - & - & - & - & 2 & 2 \\
\hline Not indicated & 2 & 5.80 & - & - & - & - & 2 & 2 \\
\hline Total & 35 & 100 & 32 & 100 & 33 & 100 & 100 & 100 \\
\hline
\end{tabular}

$\mathrm{NCTG}=$ number in contractor's group; $\mathrm{NCLG}=$ number in clients' group; $\mathrm{NCSG}=$ number in consultants' group; $\mathrm{NTOTG}=$ number in all the groups; $\mathrm{CTG}=$ contractors' group; $\mathrm{CLG}=$ clients' group; $\mathrm{CSG}=$ consultants' group; TOTG $=$ Total in all groups 
Table 4. Experience of organizations' representatives in the construction industry

\begin{tabular}{|c|c|c|c|c|c|c|c|c|}
\hline Years of experience & YCTG & \%CG & YCLG & \%CLG & YCSG & \%CSG & YTOTG & \%TOTG \\
\hline Less than 4 years & 2 & 5.70 & 3 & 9.40 & 1 & 3.00 & 6 & 6 \\
\hline 5 to 8 & 3 & 8.60 & 7 & 21.90 & 6 & 18.20 & 16 & 16 \\
\hline 9 to 12 & 8 & 22.80 & 4 & 12.50 & 5 & 15.20 & 17 & 17 \\
\hline 13 to 15 & 7 & 20.00 & 4 & 12.50 & 7 & 21.20 & 18 & 18 \\
\hline Above 15 & 15 & 42.90 & 14 & 43.80 & 12 & 36.40 & 41 & 41 \\
\hline Not indicated & - & - & - & - & 2 & 6.10 & 2 & 2 \\
\hline Total & & 100 & & 100 & & 100 & & 100 \\
\hline
\end{tabular}

Table 5. Mean item scores and ranking of issues on traditional procurement

\begin{tabular}{|c|c|c|c|c|c|c|c|c|c|}
\hline $\mathrm{S} / \mathrm{N}$ & Issue & MCR & RCR & MCS & $\mathrm{RCS}$ & $\mathrm{MCL}$ & RCL & Mean & COR \\
\hline 1 & Where sought at all, inputs of contractors are at best advisory & 2.77 & 1 & 2.61 & 2 & 2.59 & 5 & 2.66 & 1 \\
\hline 2 & $\begin{array}{c}\text { Individual participants are exploitative of loopholes in contract } \\
\text { documents }\end{array}$ & 2.54 & 6 & 2.45 & 5 & 2.81 & 1 & 2.60 & 2 \\
\hline 3 & It discourages innovation on part of contractors & 2.66 & 2 & 2.39 & 10 & 2.63 & 4 & 2.54 & 3 \\
\hline 4 & $\begin{array}{l}\text { it discourages cooperation and collaboration among project } \\
\text { participants }\end{array}$ & 2.51 & 9 & 2.39 & 10 & 2.66 & 3 & 2.53 & 4 \\
\hline 5 & $\begin{array}{l}\text { There is uneven, unclear and unfair allocation of risks to some } \\
\text { participants }\end{array}$ & 2.57 & 4 & 2.55 & 4 & 2.34 & 13 & 2.50 & 5 \\
\hline 6 & $\begin{array}{l}\text { It encourages participants to be more profit conscious instead of } \\
\text { client/customer conscious }\end{array}$ & 2.26 & 19 & 2.45 & 5 & 2.72 & 2 & 2.49 & 6 \\
\hline 7 & It encourages claim consciousness among participants & 2.37 & 16 & 2.76 & 1 & 2.28 & 17 & 2.48 & 7 \\
\hline 8 & Does not create a win-win situation among project participants & 2.54 & 7 & 2.58 & 3 & 2.28 & 16 & 2.47 & 8 \\
\hline 9 & $\begin{array}{c}\text { Communication and transfer of useful knowledge among project } \\
\text { participants is difficult }\end{array}$ & 2.57 & 4 & 2.42 & 7 & 2.38 & 10 & 2.46 & 9 \\
\hline 10 & Seeking inputs of contractors s not mandatory but optional & 2.54 & 7 & 2.42 & 7 & 2.41 & 8 & 2.44 & 10 \\
\hline 11 & It engenders a climate of conflict among participants & 2.43 & 13 & 2.30 & 15 & 2.41 & 8 & 2.40 & 11 \\
\hline 12 & It is more protective of clients than other participants & 2.37 & 16 & 2.36 & 12 & 2.41 & 8 & 2.39 & 12 \\
\hline 13 & $\begin{array}{c}\text { Detached objectivity of participants is doubtful- each is interested } \\
\text { in what he can gain from the project }\end{array}$ & 2.60 & 3 & 2.27 & 17 & 2.31 & 14 & 2.39 & 12 \\
\hline 14 & It encourages confrontation of persons instead of issues & 2.29 & 18 & 2.30 & 15 & 2.50 & 6 & 2.38 & 14 \\
\hline 15 & $\begin{array}{l}\text { It encourages professional mistrust and rivalry among } \\
\text { participants }\end{array}$ & 2.43 & 13 & 2.27 & 17 & 2.34 & 13 & 2.37 & 15 \\
\hline 16 & There is master servant relationship among participants & 2.51 & 9 & 2.31 & 14 & 2.16 & 19 & 2.35 & 16 \\
\hline 17 & $\begin{array}{c}\text { It does not encourage commitment to project objectives rather } \\
\text { individual participants objectives }\end{array}$ & 2.23 & 20 & 2.42 & 7 & 2.31 & 14 & 2.34 & 17 \\
\hline 18 & It increases exposure of participants to litigation & 2.46 & 12 & 2.33 & 13 & 2.19 & 18 & 2.34 & 17 \\
\hline 19 & $\begin{array}{c}\text { It does not encourage commitment of all participants to total } \\
\text { quality right from project design }\end{array}$ & 2.49 & 11 & 2.09 & 19 & 2.34 & 13 & 2.32 & 19 \\
\hline 20 & Relationships among participants breed mistrust & 2.40 & 15 & 2.03 & 20 & 2.06 & 20 & 2.19 & 20 \\
\hline
\end{tabular}

$\mathrm{MCR}=$ mean item score for contractor's group; RCR = ranking in contractors' group; $\mathrm{MCS}=$ mean item score for Consultants' group; $\mathrm{RCS}=$ ranking in consultants' group; $\mathrm{MCL}=$ mean item score for clients' group; $\mathrm{RCL}$ = ranking in clients' group; $\mathrm{COM}=$ aggregated mean of the three groups; $\mathrm{COR}=$ aggregated ranking of the three groups. 
Table 6. Results of Kruskal Wallis test on traditional procurement issues

\begin{tabular}{|c|c|c|c|c|c|c|c|}
\hline Issue raised on traditional procurement & $\begin{array}{c}\text { CTM } \\
\text { R }\end{array}$ & $\begin{array}{c}\text { CSM } \\
\mathrm{R}\end{array}$ & $\begin{array}{c}\text { CLM } \\
\text { R }\end{array}$ & $\begin{array}{l}\text { Chi-squ } \\
\text { are }\end{array}$ & d.f & Sig. & Decision \\
\hline $\begin{array}{c}\text { It discourages cooperation and collaboration } \\
\text { among project participants }\end{array}$ & 49.36 & 47.80 & 52.91 & 0.570 & 2 & 0.572 & Accept $\mathrm{H}_{0}$ \\
\hline $\begin{array}{l}\text { It does not encourage commitment to project } \\
\text { objectives rather individual participant's objectives }\end{array}$ & 47.16 & 53.58 & 49.53 & 0.924 & 2 & 0.630 & Accept $\mathrm{H}_{0}$ \\
\hline $\begin{array}{c}\text { It encourages confrontation of persons instead of } \\
\text { issues }\end{array}$ & 48.03 & 49.28 & 52.88 & 0.544 & 2 & 0.762 & Accept $\mathrm{H}_{0}$ \\
\hline $\begin{array}{c}\text { It encourages professional mistrust and rivalry } \\
\text { among participants }\end{array}$ & 50.99 & 50.00 & 48.92 & 0.093 & 2 & 0.954 & Accept $\mathrm{H}_{0}$ \\
\hline $\begin{array}{l}\text { It encourages claim consciousness among } \\
\text { participants }\end{array}$ & 47.56 & 56.45 & 46.22 & 2.769 & 2 & 0.25 & Accept $\mathrm{H}_{0}$ \\
\hline $\begin{array}{l}\text { It encourages participants to be more profit } \\
\text { conscious instead of client/customer conscious }\end{array}$ & 44.20 & 49.94 & 56.41 & 3.279 & 2 & 0.194 & Accept $\mathrm{H}_{0}$ \\
\hline $\begin{array}{l}\text { Individual participants are exploitative of loopholes } \\
\text { in contract documents }\end{array}$ & 48.97 & 46.06 & 55.06 & 1.771 & 2 & 0.412 & Accept $\mathrm{H}_{0}$ \\
\hline It engenders a climate of conflict among participants & 50.31 & 48.72 & 50.94 & 0.113 & 2 & 0.945 & Accept $\mathrm{H}_{0}$ \\
\hline $\begin{array}{c}\text { There is master servant relationship among } \\
\text { participants }\end{array}$ & 55.70 & 48.42 & 45.34 & 2.536 & 2 & 0.281 & Accept $\mathrm{H}_{0}$ \\
\hline Relationships among participants breed mistrust & 56.13 & 46.59 & 46.70 & 2.756 & 2 & 0.252 & Accept $\mathrm{H}_{0}$ \\
\hline $\begin{array}{c}\text { Seeking inputs of contractors s not mandatory but } \\
\text { optional }\end{array}$ & 51.71 & 48.50 & 49.63 & 0.246 & 2 & 0.884 & Accept $\mathrm{H}_{0}$ \\
\hline $\begin{array}{l}\text { Where sought at all, inputs of contractors are at best } \\
\text { advisory }\end{array}$ & 52.70 & 47.56 & 49.48 & 0.679 & 2 & 0.712 & Accept $\mathrm{H}_{0}$ \\
\hline $\begin{array}{l}\text { Does not create a win-win situation among } \\
\text { project participants }\end{array}$ & 51.93 & 52.17 & 45.72 & 1.168 & 2 & 0.558 & Accept $\mathrm{H}_{0}$ \\
\hline $\begin{array}{l}\text { Detached objectivity of participants is doubtful-each } \\
\text { is interested in what he can gain from the project }\end{array}$ & 54.44 & 46.81 & 48.33 & 1.448 & 2 & 0.485 & Accept $\mathrm{H}_{0}$ \\
\hline It is more protective of clients than other participants & 48.81 & 50.30 & 51.00 & 0.111 & 2 & 0.948 & Accept $\mathrm{H}_{0}$ \\
\hline $\begin{array}{l}\text { There is uneven, unclear and unfair allocation of } \\
\text { risks to some participants }\end{array}$ & 51.64 & 51.69 & 46.52 & 0.828 & 2 & 0.661 & Accept $\mathrm{H}_{0}$ \\
\hline It increases exposure of participants to litigation & 53.30 & 49.69 & 46.70 & 0.982 & 2 & 0.612 & Accept $\mathrm{H}_{0}$ \\
\hline It discourages innovation on part of contractors & 51.66 & 46.83 & 51.36 & 0.620 & 2 & 0.734 & Accept $\mathrm{H}_{0}$ \\
\hline $\begin{array}{l}\text { Communication and transfer of useful knowledge } \\
\text { among project participants is difficult }\end{array}$ & 52.41 & 49.44 & 47.92 & 0.465 & 2 & 0.793 & Accept $\mathrm{H}_{0}$ \\
\hline $\begin{array}{l}\text { It does not encourage commitment of all } \\
\text { participants to total quality right from project design }\end{array}$ & 53.50 & 45.70 & 50.47 & 1.313 & 2 & 0.519 & Accept $\mathrm{H}_{0}$ \\
\hline
\end{tabular}

